\title{
A rare case: Isolated superior mesenteric vein injury occurring after blunt abdominal trauma
}

\author{
(1) Mehmet Kubat, M.D.
}

Department of General Surgery, Alaaddin Keykubat University Alanya Training and Research Hospital, Antalya-Turkey

\begin{abstract}
Intraabdominal vascular injuries due to blunt abdominal trauma are rare. It is very difficult to visualize superior mesenteric vein (SMV) and portal vein injuries under emergency conditions. In this case study, we reported a low-speed car accident, a patient with isolated SMV injury as a result of a blunt abdominal trauma that arose from a collision with a steering wheel. A 62-year-old male patient was admitted to the emergency department with minimal distention and diffuse tenderness in the abdomen. The presence of diffuse fluid in the abdomen and suspected liver injury were reported in ultrasonography. The presence of fluid in perihepatic and perisplenic areas was detected in abdominal tomography. No solid organ injury was observed. Laparotomy revealed an injury in the small intestine mesentery. There was a defect on SMV under splenic vein combination. End side vein anastomosis and primary repair were performed. During six months follow-up, the patient did not have active complaints, and there was no pathology in the SMV and portal vein. We think that the use of vascular repair techniques applied by experienced surgeons in hemodynamically stable superior mesenteric venous injuries is important concerning continuity of anatomical and functional integrity.
\end{abstract}

Keywords: Blunt abdominal trauma; injury; superior mesenteric vein.

\section{INTRODUCTION}

Blunt and penetrating abdominal traumas affect primarily solitary and hollow organs. Abdominal vascular injuries are associated with high mortality and morbidity and often arise from penetrating traumas. Intraabdominal vascular injuries that arise from blunt abdominal trauma are rare, and blunt abdominal traumas resulting in an isolated superior mesenteric vein (SMV) injuries are extremely rare. ${ }^{[1]}$

Visualizations of the superior mesenteric vein and the portal vein are extremely difficult in emergency situations, and the difficulty in isolating injured vessels and the presence of other accompanying major abdominal injuries result in increased mortality and morbidity. ${ }^{[2]}$ The ligation of the relevant vessel is one option in cases with unstable hemodynamic status, although the method is associated with congestive complications. ${ }^{[3,4]}$ This case report presents a patient who sustained a blunt abdominal trauma from a steering wheel during a lowvelocity road traffic accident and relays our approach to the treatment.

\section{CASE REPORT}

A 62-year-old male patient was admitted to the emergency room after sustaining a blunt abdominal trauma during a road traffic accident. In an examination of the accident records, it was realized that the accident occurred at a velocity of 20 $\mathrm{km} / \mathrm{h}$ and that the patient's abdomen hit the steering wheel, as he was not restrained by a seat belt.

The patient's medical history was unremarkable, other than hypertension. An initial physical examination upon arrival to the emergency room revealed a Glasgow Coma Scale score of I 5; blood pressure I30/90 mmHg; pulse 92 bpm; and $\mathrm{SpO}_{2} 97$ percent. A physical examination revealed minimal abdominal

Cite this article as: Kubat M. A rare case: Isolated superior mesenteric vein injury occurring after blunt abdominal trauma. Ulus Travma Acil Cerrahi Derg 2020;26:493-495.

Address for correspondence: Mehmet Kubat, M.D.

Alaaddin Keykubat Üniversitesi Alanya Eğitim ve Araştırma Hastanesi, Genel Cerrahi Anabilim Dalı, Antalya, Turkey

Tel: +90 242 - 513484 I E-mail: dr.m.kubat@gmail.com

Ulus Travma Acil Cerrahi Derg 2020;26(3):4963-495 DOI: 10.14744/tjtes.2019.39932 Submitted: 17.02.2019 Accepted: 17.06.2019 Online: 13.05.2020

Copyright 2020 Turkish Association of Trauma and Emergency Surgery 
distension and diffuse tenderness, while other system examinations uncovered no other additional pathological findings. Hemoglobin was $15 \mathrm{~g} / \mathrm{dl}$, and hematocrit was 44.3 percent.

An emergency abdominal ultrasonography revealed the presence of extensive intraabdominal fluid and suspected liver injury, and a subsequent abdominal computed tomography detected perihepatic and perisplenic fluid that was possibly hemorrhagic in nature (Fig. I). There was no evidence of solid organ injury, and thoracic and pelvic CT scans revealed no pathology.

Immediate fluid resuscitation was initiated with a $1,000 \mathrm{ml}$ crystalloid solution, and a laparotomy was performed at one hour after admission to the emergency room. Blood pressure was $90 / 60 \mathrm{mmHg}$ and the pulse rate was $110 \mathrm{bpm}$. An exploration revealed approximately $3,000 \mathrm{ml}$ of intraabdominal hemorrhagic fluid, but no solid or hollow organ injury. A 6-cm injury was identified at the base of the small bowel mesentery, inferior to the transverse colon mesentery, with a surrounding hematoma, and also active venous bleeding. The bleeding site was packed, and the injured site was dissected. An approximately $15 \mathrm{~mm}$ avulsion tear and defect were found above the SMV and below the confluence of the splenic vein that was considered to be secondary to traction by collateral vessels.

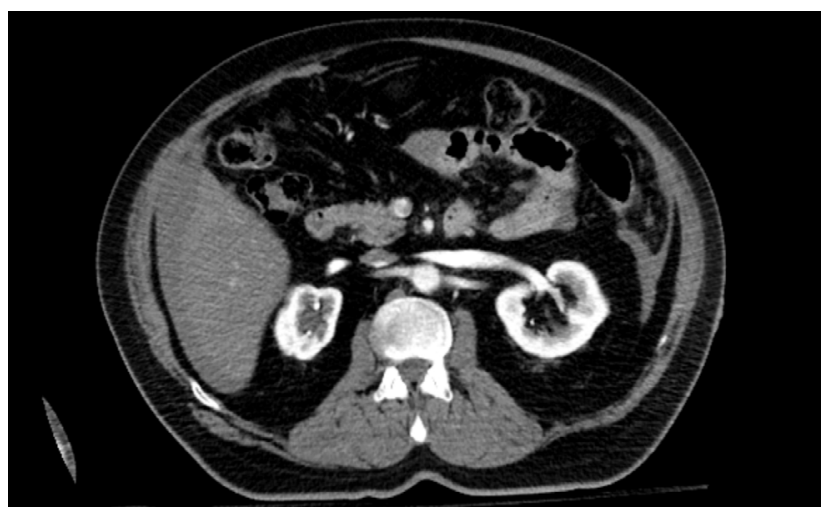

Figure 1. Abdominal tomography wiew of the patient. Presence of fluid in perihepatic and perisplenic areas.

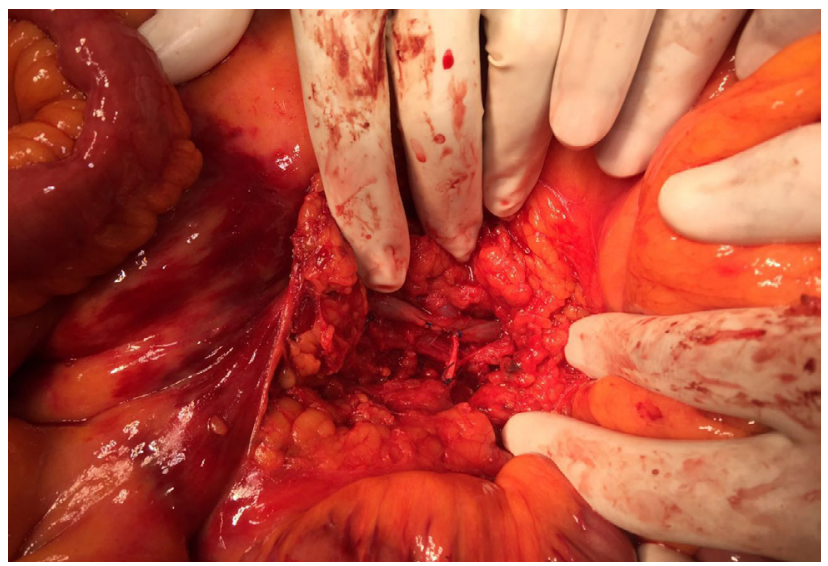

Figure 2. Intraoperative photo of the end-to-side vascular anastomosis.
An end-to-side vascular anastomosis was performed with a $5 / 0$ prolene suture, and the defect was primarily repaired (Fig. 2). The patient received three units of erythrocyte suspension, and approximately $4,000 \mathrm{ml}$ colloid volume expanders and crystalloid fluid replacement during surgery. The patient was followed up in the intensive care unit for two days after surgery, and oral intake was initiated after two days. SMV and portal venous flows were followed with $C T$ angiography and Doppler ultrasonography. After confirming that no additional pathology existed in the gastrointestinal tract of the patient and that all functions were normal, the patient was discharged on day 12 following surgery with appropriate anticoagulation therapy. During the 6-month follow-up period, the patient reported no active complaints and investigations showed no pathology in the SMV and portal vein. The follow-up program was ceased in accordance with the desire of the patient. $\mathrm{Pa}-$ tient's consent was obtained for this study.

\section{DISCUSSION}

Isolated superior mesenteric vein (SMV) injuries that arise from blunt abdominal traumas have only rarely been reported. Intraabdominal vascular injuries are often accompanied by other solid and hollow organ injuries. ${ }^{[5]}$ Killen et al. ${ }^{[6]}$ reported a 0.2 percent incidence rate for mesenteric vein injury caused by blunt abdominal trauma. Abdominal vascular injuries mostly arise from penetrating injuries and abdominal vascular injuries secondary to blunt abdominal trauma mostly arise from traffic accidents. ${ }^{[7]}$

Mesenteric vascular injuries due to blunt abdominal trauma often occur as a result of opposing forces exerted by the mesentery itself against its fixed point. In a study of 302 patients with abdominal vascular injuries reported by Ansesio et al., ${ }^{[1]}$ SMV was the second most commonly affected vein $(n=33,13 \%)$ and 19 patients had isolated SMV injuries. The rate of mortality associated with isolated injuries was 52.7 percent, while in another study, a mortality rate of 45 percent was reported associated with isolated superior mesenteric vein injury. ${ }^{[4]}$ There is a lack of consensus on the treatment options in SMV injuries, and at least five treatment methods have been described as follows: ligation, lateral repair, endto-end anastomosis, and autologous and prosthetic grafting. A simple ligation must be preferred in patients with unstable or multiple injuries due to venous congestion and similar complications. ${ }^{[5,7]}$ Collaterals that will develop with retroperitoneal Retzius veins are important in this approach, and this allows faster hemodynamic stability. Donahue and Strauch ${ }^{[8]}$ found that patients undergoing ligation had higher survival rates $(85 \%)$ than those undergoing venography $(64 \%)$.

The selection of vessel repair methods in mesenteric vein injuries would be more appropriate concerning anatomic and functional considerations, although these methods come with technical difficulties. Kostka et al. ${ }^{[9]}$ reported on a patient who was treated with end-to-end anastomosis and who suffered no additional problems in the follow-up period. In the same 
patient, the gastrointestinal passage returned to normal at postoperative day 9 , and the patient was discharged on day 20. The patient in the present was started on the oral intake of liquid food at postoperative day 2 and was discharged on postoperative day 12. Miyauchi et al. ${ }^{[3]}$ stated that three weeks should elapse following ligation for the development of collateral vessels and the regression of congestion and edema in the small bowel. Tulip et al. ${ }^{[10]}$ reported on a patient who developed overwhelming small bowel edema with the formation of thrombosis in the collateral vessels and SMV following vessel ligation, and carried out bypass surgery between the SMV and splenic vein using the autologous femoral vein. Ball et al. ${ }^{[1]}$ performed a vessel ligation on a female patient with an SMV injury who was hemodynamically unstable and had to perform saphenous vein graft due to the identification of small bowel ischemia on a control laparotomy. It is apparent that the functions of the gastrointestinal tract following vessel ligation return to normal over a long period, and may even lead to ischemia. On the other hand, Coimbra et al..$^{[5]}$ reported on a patient who developed thrombosis and extensive small bowel necrosis following SMV resection and end-to-end anastomosis. Although no such similar situation was noted in the present patient, we were well aware that such complications could not be ruled out.

\section{Conclusion}

Despite their rare occurrence, superior mesenteric venous injuries that arise from blunt abdominal traumas are associated with high mortality due to the challenges faced in diagnosis and the isolation of the injured structures. Although ligation is preferable in hemodynamically unstable patients, the long time needed for the development of collateral vessels and the development of small bowel congestions and edema is important drawbacks. The author considers the use of vascular repair techniques performed by experienced surgeons on hemodynamically stable patients to be important for the maintenance of anatomical and functional integrity.
Informed Consent: Written informed consent was obtained from the patient for the publication of the case report and the accompanying images.

Peer-review: Internally peer-reviewed.

Conflict of Interest: None declared.

Financial Disclosure: The authors declared that this study has received no financial support.

\section{REFERENCES}

1. Asensio JA, Chahwan S, Hanpeter D, Demetriades D, Forno W, Gambaro E, et al. Operative management and outcome of 302 abdominal vascular injuries. Am J Surg 2000;180:528-33; discussion 533-4. [CrossRef]

2. Fraga GP, Bansal V, Fortlage D, Coimbra R. A 20-year experience with portal and superior mesenteric venous injuries: has anything changed?. Eur J Vasc Endovasc Surg 2009;37:87-91. [CrossRef]

3. Miyauchi M, Kushimoto S, Kawai M, Yokota H. Postoperative course after simple ligation for superior mesenteric vein injury caused by blunt abdominal trauma: report of a case. J Nippon Med Sch 2011;78:116-9.

4. Asensio JA, Petrone P, Garcia-Nuñez L, Healy M, Martin M, Kuncir E. Superior mesenteric venous injuries: to ligate or to repair remains the question. J Trauma 2007;62:668-75. [CrossRef]

5. Coimbra R, Filho AR, Nesser RA, Rasslan S. Outcome from traumatic injury of the portal and superior mesenteric veins. Vasc Endovascular Surg 2004;38:249-55. [CrossRef]

6. Killen DA. Injury of the Superior Mesenteric Vessels Secondary to Nonpenetrating Abdominal Trauma. Am Surg 1964;30:306-12.

7. Courcy PA, Brotman S, Oster-Granite ML, Soderstrom CA, Siegel JH, Cowley RA. Superior mesenteric artery and vein injuries from blunt abdominal trauma. J Trauma 1984;24:843-5. [CrossRef]

8. Donahue TK, Strauch GO. Ligation as definitive management of injury to the superior mesenteric vein. J Trauma 1988;28:541-3. [CrossRef]

9. Kostka R, Sojáková M. Isolated superior mesenteric vein injury from blunt abdominal trauma: report of a case. Surgery today 2006;36:190-2.

10. Tulip HH, Smith SV, Valentine RJ. Delayed reconstruction of the superior mesenteric vein with autogenous femoral vein. J Vasc Surg 2012;55:1773-4. [CrossRef]

11. Ball CG, Kirkpatrick AW, Smith M, Mulloy RH, Tse L, Anderson IB. Traumatic Injury of the Superior Mesenteric Vein: Ligate, Repair or Shunt?. Eur J Trauma Emerg Surg 2007;33:550-2. [CrossRef]

\section{OLGU SUNUMU - ÖZET}

\section{Nadir bir olgu: Künt abdominal yaralanma sonucu gelişen izole süperiyor mezenterik ven yaralanmasi \\ Dr. Mehmet Kubat \\ Alaaddin Keykubat Üniversitesi Alanya Eğitim ve Araştırma Hastanesi, Genel Cerrahi Anabilim Dalı, Antalya}

Künt karın travmalarına bağlı intraabdominal vasküler yaralanmalara ender rastlanmaktadır. Süperiyor mezenterik ven (SMV) ve portal ven yaralanmalarının acil şartlarda görüntülenmesi oldukça zordur. Bu yazıda, düşük hızı araç içi trafik kazasında direksiyon simidine çarpma ile oluşan künt batın travması sonucu izole SMV yaralanması olan hasta ve tedavi yaklaşımımız sunuldu. Altmış iki yaş erkek hasta acil servise girişini takiben yapılan muayenesinde karında minimal distansiyon ve yaygın hassasiyet olduğu görüldü. Ultrasonografisinde, karın içerisinde yaygın mayi varlığı ve şüpheli karaciğer yaralanması bildirildi. Abdominal tomografide perihepatik ve perisplenik alanlarda sıvı varlığı saptandı. Solid organ yaralanmasının olmadığı görüldü. Laparatomide ince bağırsak mezenterinde yaralanma görüldü. SMV üzerinde splenik ven birleşimi altında defekti mevcuttu. Uç yan damar anastomozu ve primer onarım gerçekleştirildi. Altı ay süreyle yapılan takiplerinde hastanın aktif şikâyeti olmadığı, yapılan tetkikler sonucunda SMV ve portal ven de patoloji olmadığı görüldü. Hemodinamik açıdan stabil olan süperior mezenterik venöz yaralanmalarında tecrübeli cerrahlarca uygulanan vasküler onarım tekniklerinin kullanılmasının anatomik ve fonksiyonel bütünlüğün devamlılığı açısından önemli olduğunu düşünmekteyiz.

Anahtar sözcükler: Künt abdominal travma; süperiyor mezenterik ven; yaralanma.

Ulus Travma Acil Cerrahi Derg 2020;26(3):493-495 doi: 10.14744/tjtes.2019.39932 